\title{
Anti-Corruption Potential of Prohibiting the Financing of Election Campaigns by Commercial Organizations
}

\author{
Evgenii A. Akunchenko, Irina A. Damm, \\ Viktoriia V. Kostrykina and Pavel V. Teplyashin* \\ Siberian Federal University \\ Krasnoyarsk, Russian Federation
}

Received 05.03.2021, received in revised form 29.04.2021, accepted 11.05.2021

\begin{abstract}
The problem of political corruption is particularly relevant for modern criminological science. The processes of formation and functioning of power, due to their high social significance, have long been subject to negative corruption, and therefore they need a special protection mechanism. The subject of the study is the legal regulation of banning the financing of political activities (election campaigns), as well as its reflection in the local regulations of commercial organizations. The article presents a general description of the illegal financing of election campaigns as a form of political corruption, describes the problems of applying measures of retrospective responsibility in relation to its subjects, and also evaluates the effectiveness of banning the financing of political activities (election campaigns) in the system of preventing this form of corruption. To study the practice of regulating the prohibition in question at the level of local regulations of commercial organizations, the authors conducted monitoring of the official websites of 250 major Russian companies based on the methods of statistical analysis of sociolegal phenomena and processes. The results of the study allow us to conclude that it is necessary to take a set of measures aimed at encouraging commercial organizations to adopt anti-corruption compliance programs which will include a ban on financing political activities (election campaigns), as well as aimed at limiting the possibility of committing relevant corruption offenses.
\end{abstract}

Keywords: corruption, political system, elections, electoral process, campaign finance, election fund, anti-corruption compliance, corruption prevention, criminal liability of legal entities.

The reported study was funded by RFBR, project number 20-311-90028.

Research area: law.

(C) Siberian Federal University. All rights reserved

* Corresponding author E-mail address: eakunchenko@gmail.com, idamm@yandex.ru, v.kostrykina@mail.ru, pavlushat@mail.ru ORCID: 0000-0002-9030-7422 (Akunchenko); 0000-0001-6286-374X (Damm); 0000-0001-9874-9308 (Kostrykina); 00000002-6737-749X (Teplyashin) 
Citation: Akunchenko, E.A., Damm, I.A., Kostrykina, V.V., Teplyashin, P.V. (2021). Anti-corruption potential of prohibiting the financing of election campaigns by commercial organizations. J. Sib. Fed. Univ. Humanit. Soc. Sci., 14(5), 680-692. DOI: 10.17516/1997-1370-0751.

\title{
Антикоррупционный потенциал запрета на финансирование избирательных кампаний в деятельности коммерческих организаций
}

\author{
Е.А. Акунченко, И.А. Дамм, \\ В.В. Кострыкина, П.В. Тепляшин \\ Сибирский федеральный университет \\ Российская Федерачия, Красноярск
}

\begin{abstract}
Аннотация. Проблема политической коррупции особенно актуальна для современной криминологической науки. Процессы формирования и функционирования власти, в силу своей высокой социальной значимости, с давних времен подвержены негативному коррупционному воздействию, в связи с чем они нуждаются в особом механизме охраны. Предметом исследования выступило правовое регулирование запрета на финансирование политической деятельности (избирательных кампаний), а также его отражение в локальных нормативных актах коммерческих организаций. В статье представлена общая характеристика незаконного финансирования избирательных кампаний как одной из форм политической коррупции, изложены проблемы применения мер ретроспективной ответственности в отношении ее субъектов, а также оценена эффективность запрета на финансирование политической деятельности (избирательных кампаний) в системе предупреждения данной формы коррупции. Для изучения практики регламентации рассматриваемого запрета на уровне локальных нормативных актов коммерческих организаций на основе методов статистического анализа социально-правовых явлений и процессов проведен контент-анализ официальных сайтов 250 крупнейших российских компаний. Результаты исследования позволяют сделать вывод о необходимости принятия комплекса мер, направленных на стимулирование коммерческих организаций к принятию антикоррупционных комплаенс-программ и включению в них запрета на финансирование политической деятельности (избирательных кампаний), а также ориентированных на ограничение возможности совершения соответствующих коррупционных правонарушений.
\end{abstract}

Ключевые слова: коррупция, политическая система, выборы, избирательный процесс, финансирование избирательных кампаний, избирательный фонд, антикоррупционный комплаенс, предупреждение коррупции, уголовная ответственность юридических лиц.

Исследование выполнено при финансовой поддержке РФФИ в рамках научного проекта № 20-311-90028.

Научная специальность: 12.00.00 - юридические науки. 


\section{Введение в проблему исследования}

В Стратегии национальной безопасности РФ коррупция признается препятствием устойчивому развитию и реализации стратегических национальных приоритетов. Обладая сложной многоуровневой структурой, данное явление представляет опасность для большинства сфер общественной жизни и в случае широкого распространения способно причинить невосполнимый вред основополагающим социальным институтам. В специальной литературе подчеркивается, что системная коррупция имеет разнообразные и долговременные негативные последствия: торможение экономического развития за счет устранения свободной экономической конкуренции, монополизма и ухудшения инвестиционного климата; стимулирование роста цен и расширение теневой экономики; подрыв доверия населения к власти, создание нежелательного имиджа для страны и ее руководства за рубежом, разрушение принципов законности и независимости правосудия; усиление социальной напряженности и подрыв общественной безопасности; укрепление правового нигилизма и пр. (Nomokonov, 2013: 62).

Проблема коррупции характерна для многих государств, и наша страна в данном случае не исключение. На текущий момент правоохранительные органы предпринимают значительные усилия по выявлению, пресечению, раскрытию и расследованию коррупционных правонарушений. По данным Генеральной прокуратуры РФ, в 20192020 гг. зарегистрировано более 60 тыс. преступлений коррупционной направленности, размер возмещенного материального ущерба от которых составил более 13 млрд руб. (Statistic Data, 2020). Вместе с тем, как следует из ежегодного доклада Transparency International, Россия продолжает находиться в числе стран с высоким уровнем восприятия коррупции и в 2020 г. заняла 129 -е место в общемировом рейтинге (CPI, 2021). Несмотря на то что деятельность упомянутой международной организации во многом политизирована и требует взвешенной оценки (Kleimenov, 2020: 536), отечественные исследователи также регулярно указывают на недостатки системы противодействия коррупции (Astanin, 2016; Gorshenkov, 2016; Kabanov, 2018; Kleimenov, 2018; Kozlov, 2020; Matskevich \& Aminov, 2017; Nomokonov, 2014; Shchedrin, 2018; Tsirin, 2016; Zhubrin \& Ilii, 2017 , etc.). В частности, на практике наблюдается недооценка эффективности мер, нацеленных не на борьбу с коррупцией, а на ее предупреждение. Сказанное актуализирует исследовательский интерес к разработке действенного механизма антикоррупционной профилактической работы, направленной на снижение уровня коррупционной преступности за счет перспективного воздействия на коренные причины и условия ее существования. Поскольку политическая система выступает основой государственности, изучение коррупционных проявлений в рассматриваемой сфере особенно важно.

\section{Концептологические \\ основания исследования}

Коррупция как общественно опасное явление возникла одновременно с формированием социальных порядков и структур, направленных на организацию и управление коллективной деятельностью людей (Nisnevich, 2015: 90). По своей природе она неотделима от власти и, как следствие, особенно заметна в сфере политической жизни общества. История человечества знает множество примеров того, как коррумпированность правителей приводила к дестабилизации социально-экономических процессов, войнам и революциям. Политическая коррупция относится к числу наиболее древних видов коррупции и с давних времен встречает противодействие со стороны государственного аппарата. Так, по праву Римской республики деяния, совершаемые с целью подрыва позиций политического противника и оказания влияния на результаты выборов путем прямого подкупа или других форм воздействия на избирателей, признавались уголовным преступлением (Rogachevskii, 2015: 176).

В современном мире политическая коррупция представляет угрозу национальной безопасности, поскольку разрушительное 
воздействие данного явления затрагивает конституционные основы государственного устройства. Если фундаментальный механизм воспроизводства и осуществления власти настроен неверно, то он не будет надлежащим образом работать в любых других отраслях государственного управления. Иными словами, неразрешенные проблемы коррупции в стержневом механизме функционирования общества всегда будут давать метастазы в другие части политической системы, бесконечно питать и вдохновлять коррупционные практики (Sheverdiaev, 2020).

Политическая коррупция - это социально-правовое и политикокриминологическое явление, выражающееся в совокупности совершенных преступлений должностными лицами органов государственной власти и местного самоуправления или претендентами на эти должности либо по их поручению другими лицами с использованием своего служебного, имущественного или иного положения вопреки интересам других лиц и общества в целях занятия, сохранения, распределения или утраты соответствующей государственной должности, в определенном государстве (или регионе) за определенный период времени (Kabanov, 2004: 73). Негативные последствия политической коррупции очевидны, к их числу относится снижение доверия общества к государственной и местной власти, усиление социальной напряженности, нарушение политической стабильности, провоцирование коллективной реакции в виде различных протестов и забастовок. Как отмечается, одним из опаснейших последствий политической коррупции нужно признать «цветные революции», которые становятся возможными из-за роста недовольства значительных масс населения действиями (бездействием) властей соответствующего уровня по решению волнующих граждан проблем (Feshchenko, 2015).

Политическая коррупция многогранна, и далеко не все ее негативные проявления получили должное осмысление в научнопрактической литературе. Одной из обще- ственно опасных форм политической коррупции, способной оказать деструктивное воздействие на процессы формирования органов государственной власти и местного самоуправления, выступает незаконное оказание и получение материально-финансовой поддержки на выборах (Akunchenko, 2020: 86-87; Damm, 2006: 65-67; Kabanov, 2004: 64-66; Nisnevich, 2012: 193; Rose-Ackerman, 2003: 175). В рамках настоящего исследования особый интерес вызывает незаконное финансирование избирательных кампаний со стороны коммерческих организаций, поскольку на сегодняшний день основным источником формирования избирательных фондов кандидатов и политических партий выступают частные пожертвования.

Финансирование - важный элемент системы поддержки избирательного процесса, присутствующий на всех его этапах и гарантирующий проведение избирательных кампаний с материальной точки зрения (Golovin, 2016: 211). В соответствии с действующим законодательством избирательные фонды кандидатов (избирательных объединений) могут создаваться как за счет собственных средств, так и за счет добровольных пожертвований физических и юридических лиц (пп. «в» и «Гг П. 5 ст. 58 Федерального закона от 12.06.2002 № 67-Ф3 «Об основных гарантиях избирательных прав и права на участие в референдуме граждан Российской Федерации»). В научной литературе подчеркивается, что приведенная норма направлена на расширение источников финансирования избирательных кампаний и тем самым способствует усилению конкурентной борьбы в период выборов (Devitskii, 2014). Однако на практике щедрые пожертвования в избирательные фонды, поступающие от представителей крупного бизнеса и финансовопромышленных групп, представляют собой вознаграждение за последующее лоббирование их интересов со стороны избранных должностных лиц, что способно привести к снижению уровня легитимности представительной власти, детерминации политизации организованной преступности, искажению реальной политической конкуренции, 
снижению уровня доверия населения к процессу формирования власти посредством выборов, проникновению во власть лиц с криминальным прошлым, захвату власти бизнесменами не только в конкретном регионе, но и в государстве в целом, созданию нежелательного имиджа страны, нарушению принципа законности и т. д. (Damm, 2018; Kabanov, 2003).

Как и любая разновидность коррупции, незаконное финансирование избирательных кампаний со стороны коммерческих организаций имеет ряд характерных черт, к числу которых относятся сфера существования, субъектный состав и цель коррупционного поведения (деятельности) (Damm, 2003: 121). Рассмотрим их более детально.

Сферой существования данной формы коррупции является непосредственно избирательный процесс как в узком, так и широком его понимании. При этом следует отметить, что незаконное финансирование избирательных кампаний может осуществляться задолго до принятия официального решения о проведении выборов. Например, широкое распространение в последнее время получила процедура «праймериз», т. е. предварительное голосование с целью определения наиболее популярных среди сторонников партии кандидатов. Как полагает М.М. Какителашвили, главная цель праймериз для политической партии - это стремление начать агитацию, а следовательно, и ее финансирование задолго до начала установленного в законе периода (Kakitelashvili, 2017). При помощи предварительного голосования материально и финансово обеспеченное избирательное объединение получает возможность использовать свои ресурсы за рамками правового режима избирательного фонда.

Круг субъектов рассматриваемой формы коррупции составляют лица, незаконно оказывающие и получающие материальнофинансовую поддержку на выборах. К числу первых следует отнести коммерческие организации и их сотрудников (лиц, выполняющих управленческие функции в коммерческих организациях, и лиц, работающих в соответствующей коммерческой организации в ином качестве). К числу вторых - кандидатов, их доверенных лиц, уполномоченных представителей кандидатов и избирательных объединений, использующих незаконное финансирование в целях достижения определенного политического результата на выборах. В качестве особого субъекта рассматриваемой формы коррупции в литературе также называется избирательный штаб кандидата (политической партии). В частности, средства «черной кассы», формируемые избирательным штабом, предназначены для финансирования самого штаба, организации и применения «грязных» избирательных технологий, в том числе направленных на подкуп субъектов избирательного процесса (Zyrianova, 2013: 35).

Целью незаконного финансирования избирательных кампаний со стороны коммерческих организаций является противоправное извлечение различного рода выгод. В зависимости от содержания принято выделять выгоды материального и нематериального характера. К числу материальных коррупичионыьх выгод следует отнести: получение лимитированных импортных и экспортных лицензий, льготных программ кредитования, крупных государственных заказов, высокоприбыльных концессий; снижение выкупной стоимости земель; уклонение от уплаты налогов, сборов, таможенных платежей и др. В свою очередь, нематериальные коррупционные выгоды включают: последующее получение депутатского мандата с целью защиты своего бизнеса от рейдерства, получение депутатской неприкосновенности, расширение возможностей для бизнеса, знакомства с влиятельными людьми, вхождение в круг доверенных лиц, с которыми власть готова вести деловые переговоры на более дружественных условиях. В данной связи нельзя не согласиться с тем, что заинтересованность коммерческих организаций в результатах выборов в основном объясняется с точки зрения возможности получить дополнительную прибыль (или не потерпеть убытков) (Avak'ian et al., 2016: 265-266). 
Негативные последствия незаконного финансирования избирательных кампаний со стороны коммерческих организаций трудно переоценить. Наличие неограниченных материальных и финансовых ресурсов открывает широкие возможности для активного использования «грязных» избирательных технологий. Полученное при этом конкурентное преимущество создает основу для прихода к власти коррумпированных лиц, осуществляющих продвижение интересов своих жертвователей в процессе законотворческой и правоприменительной деятельности. Интерес различных финансово-промышленных групп к незаконной материальной поддержке кандидатов и политических партий вызван созданием на федеральном и региональном уровнях благоприятных условий в отношении подконтрольных сфер хозяйственной деятельности. При этом данная ситуация выгодна обеим сторонам коррупционных отношений: «коалиция исполнительной власти и финансово-промышленных групп, причем желательно нескольких, позволяет кандидату в губернаторы провести успешную кампанию и при необходимости задействовать финансовый ресурс ФПГ для стабилизации социально-экономической обстановки в случае кризисных явлений» (Grashchenkov \& Meier, 2016: 86).

Общественная опасность незаконного финансирования избирательной кампании выражается в потенциально возможной реализации сценария «захват власти». Это наглядно иллюстрирует один из немногих примеров привлечения к уголовной ответственности по ст. 141.1 УК РФ. По версии следствия, в январе - марте 2010 г. обвиняемый Ф., являясь кандидатом в депутаты гордумы Нововоронежа, незаконно использовал для ведения кампании не менее 8 млн руб., не включенных в его избирательный фонд. Через помощников и работников своего штаба он нашел два десятка местных жителей, с каждым из которых заключил письменный договор о возмездном оказании услуг. Исполнители брали на себя личное участие в собственной агиткампании, а после избрания обещали под- держать предложенные заказчиком кандидатуры спикера думы и сити-менеджера, не пропускать заседания и не слагать с себя депутатских полномочий без согласования с Ф.Сам организатор схемы собирался стать вице-спикером гордумы. Общие для всех пункты договоров касались собственно выборов: заказчик обязался направить в среднем по 1 млн руб. в «черные» кассы кандидатов и организовать им кампанию (в частности, наладить полевую сеть агитаторов и «создать некомфортные условия для оппонентов»). В результате прошедших выборов 19 из 25 мест в гордуме Нововоронежа получили выдвинутые кандидаты, которые избрали Ф. вице-спикером, а его протеже Щ. - главой Нововоронежской городской думы. Добавим, что выявить и расследовать данное преступление в большей степени удалось только потому, что участники указанной коррупционной схемы для обеспечения взаимных обязательств заключили договоры в письменной форме. Иным образом доказать привлечение денежных средств в крупном размере в рамках состава ст. 141.1 УК РФ было бы затруднительно (News, 2011).

\section{Постановка проблемы}

Анализ судебной статистики свидетельствует о том, что приведенный выше пример является едва ли не единственным (Statistic Data, 2021). Несмотря на высокую общественную опасность рассматриваемого явления, отсутствие практики привлечения к уголовной ответственности за незаконное финансирование избирательных кампаний может свидетельствовать о том, что в деятельности сотрудников правоохранительных органов и судов встречаются серьезные препятствия на пути применения действующей редакции ст. 141.1 УК РФ. Как отмечают исследователи, причин тому может быть несколько: нечеткость формулировок, лексическая перегруженность, сложность восприятия нормы (Shevchenko, 2006: 127); отсутствие соблюдения правил юридической техники (Lopashenko, 2009: 139; Turishcheva, 2010: 6); излишняя ограниченность трактовки способов соверше- 
ния данного преступления (Eliseeva, 2004: 22-23); противоречие между мерой расчета «крупного размера» как квалифицирующего признака нормы с его же минимальным допустимым пределом (Bobrova, 2013: 13; Tolstikova, 2005: 16-17) и пр.

Полагаем, что к числу проблем реализации данной нормы также следует отнести невозможность привлечения к уголовной ответственности юридических лиц. Напомним, что в соответствии с действующим российским уголовным законодательством субъектами уголовной ответственности признаются только физические лица. В случае выявления факта незаконного финансирования, попадающего под признаки состава ч. 1 ст. 141.1 УК РФ, возбудить уголовное дело в отношении коллективного субъекта не представляется возможным. Однако на практике встречаются случаи, когда компания, руководители или сотрудники которой были привлечены к уголовной ответственности, продолжала и дальше совершать преступные деяния, но уже под руководством других лиц. Для предупреждения подобных ситуаций, в зависимости от тяжести совершенного деяния, деятельность такой коммерческой организации должна быть в установленном законом порядке либо приостановлена, либо прекращена. Следует поддержать тех авторов, которые обосновывают необходимость введения института уголовной ответственности юридических лиц за совершение коррупционных деяний, следуя примеру многих зарубежных стран (Antonova, 2013: 193-194; Kashepov, 2015: 95; Fedorov, 2015: 60).

Существующая система мер ретроспективной ответственности за незаконное финансирование избирательных кампаний со стороны коммерческих организаций значительно снижает эффективность предупреждения коррупционной преступности в избирательном процессе. В этой связи становится актуальной разработка новых подходов к совершенствованию механизма охраны электоральных отношений от коррупционных посягательств. Полагаем, что одним из эффективных способов предупреждения незаконного финансирования избирательных кампаний со стороны коммерческих организаций является внутреннее (корпоративное) регулирование, устанавливающее ограничение или полный запрет на финансирование деятельности кандидатов и политических партий посредством создания системы антикоррупционного комплаенса, представляющего собой комплекс мер, нацеленных на выявление и предупреждение коррупционных рисков в деятельности организации (Astanin, 2017).

В соответствии со ст. 13.3 Федерального закона «О противодействии коррупции» организации обязаны разрабатывать и принимать меры по предупреждению коррупции. К одной из мер относится принятие кодекса этики и служебного поведения работников организации. Вместе с тем обязанность устанавливать конкретные антикоррупционные стандарты (например, запрет на незаконное финансирование избирательных кампаний) действующим законодательством не предусмотрена. Попытка восполнить данный пробел исходит от Министерства труда и социальной защиты РФ. Так, были утверждены Методические рекомендации по разработке и принятию организациями мер по предупреждению и противодействию коррупции (Methodological recommendations, 2014), coгласно которым организациям лишь рекомендуется для предупреждения коррупции предусмотреть специальные антикоррупционные стандарты в таких сферах, как спонсорская и благотворительная деятельность, взносы на политические цели, пожертвования политическим партиям.

Несмотря на отсутствие законодательной регламентации обязанности организаций устанавливать в своих локальных нормативных актах запрет на незаконное финансирование избирательных кампаний, ряд российских компаний старается придерживаться принципа неприятия коррупции в любых формах и проявлениях, устанавливая в своем корпоративном правовом регулировании запрет на финансирование политической деятельности. Вместе с тем подобная практика не является повсеместной. В целях определения состояния ло- 
кального регулирования данного запрета нами проведен мониторинг официальных сайтов крупнейших российских бизнесорганизаций.

\section{Методология}

Одним из ключевых вопросов познания социально-правовых явлений и процессов выступает определение конкретных методов исследования, а также разработка методики его проведения. В целях определения состояния локального регулирования запрета на финансирование политической деятельности были использованы такие специальные методы статистического исследования, как наблюдение, сводка и группировка.

В специальной литературе отмечается, что статистическое наблюдение представляет собой массовую регистрацию интересующих исследователя фактов в соответствии с программой статистического наблюдения (Kardopolov, 2005: 83). В свою очередь, программа наблюдения выступила в качестве методики для данного исследования. В соответствии с ней в рамках проведенного нами исследования статистическому учету подлежал факт наличия в локальных нормативных актах коммерческих организаций запрета на незаконное финансирование политической деятельности (избирательных кампаний).

Формой статистического наблюдения избран правовой мониторинг локальных нормативных актов коммерческих организаций как наиболее динамичный инструмент систематизации знаний об объекте познания.

В целях определения содержания запрета на незаконное финансирование политической деятельности (избирательных кампаний) в локальных нормативных актах бизнес-организаций проведено контентисследование официальных сайтов 250 крупнейших действующих российских коммерческих организаций (Forbes, 2020).

Полученные данные статистического наблюдения обработаны с использованием методов статистической сводки и группировки.

\section{Обсуждение}

Проведенное исследование локальных нормативных актов коммерческих организаций свидетельствует о том, что запрет на незаконное финансирование политической деятельности (избирательных кампаний) закреплен в локальных нормативных актах только $30 \%$ организаций. Анализ содержания указанных актов позволяет прийти к выводу о том, что единый подход к регулированию запрета на незаконное финансирование политической деятельности (избирательных кампаний) в настоящий момент не сложился. В частности, одни организации установили полный запрет на незаконное финансирование политической деятельности (избирательных кампаний) (ПАО «ЛУКОЙЛ», ПАО «НК «Роснефть», ПАО «Аэрофлот», ОАО «Российские железные дороги», АО «Стройтранснефтегаз» и др.), а другие связали действие данного запрета с наличием особых обстоятельств (например, ПАО «МегаФон» устанавливает действие данного запрета только в рабочее время).

Обращает внимание тот факт, что рассматриваемый антикоррупционный стандарт отсутствует в локальных нормативных актах более половины (70 \%) исследованных коммерческих организаций. Причины этого могут быть различны. Полагаем, что к одной из них следует отнести дефицит стимулирующих мер, побуждающих компании к добропорядочному ведению бизнеса, со стороны как государства, так и руководства коммерческой организации.

Декларацией $\mathrm{OOH}$ о борьбе с коррупцией и взяточничеством в международных коммерческих операциях государствамучастникам предписывается разрабатывать или поощрять разработку кодексов поведения в области предпринимательской деятельности, стандартов или оптимальной практики, которые запрещают коррупцию, взяточничество и связанные с ними противоправные действия при осуществлении международных коммерческих операций (п. 6). Полагаем, что данный принцип может быть использован в рамках не только 
международной, но и внутригосударственной коммерческой деятельности.

Необходимо отметить, что действующее антикоррупционное законодательство РФ подобных поощрений не содержит. Схожий стимулирующий эффект предполагает возможность освобождения организации от административной ответственности за коррупционное правонарушение в случае проведения организациями своевременной работы по выявлению, раскрытию и расследованию коррупционного деяния (прим. 5 к ст. 19.28 КоАП РФ). Вместе с тем реализация данной меры имеет ретроспективный характер и не направлена на предупреждение коррупционных правонарушений в будущем.

Особый интерес в данном случае вызывает зарубежное законодательство, где разработка и реализация антикоррупционных комплаенс-программ выступает смягчающим обстоятельством или основанием для освобождения от юридической ответственности организаций, сотрудники которых допустили коррупционные деяния (Liu \& Liu, 2017). Более того, согласно законодательству Бразилии, для организаций предусматривается наказание в виде штрафа в случае отсутствия у нее действующей антикоррупционной комплаенс-программы (Antonova, 2020).

В этой связи представляется разумным, если учредительные документы организации (при ее создании или текущей деятельности) должны будут содержать в себе обязанность исполнительного органа разработать и утвердить антикоррупционную комплаенс-программу соответствующей организации, а также установить в ней запрет на незаконное финансирование политической деятельности (избирательных кампаний). Отсутствие данного положения в проекте учредительного документа может служить основанием для отказа в дальнейшей регистрации организации. Сказанное очень актуально для вновь создающихся коммерческих организаций.

Мотивационными составляющими добропорядочного ведения бизнеса также следует признать присоединение организаций к Антикоррупционной хартии российского бизнеса и последующую успешную антикоррупционную практику (не менее двух лет) в части соблюдения запрета на незаконное финансирование политической деятельности (избирательных кампаний). Антикоррупционная хартия представляет собой свод антикоррупционных правил ведения бизнеса и основывается на принципе прозрачности при осуществлении компанией любых пожертвований. Такая поддержка не должна быть скрытой формой взяточничества. Присоединение организаций к Антикоррупционной хартии и соблюдение запрета на незаконное финансирование политической деятельности (избирательных кампаний) могли бы повысить репутационный уровень организации не только на национальной, но и на международной арене, сократить риск преследования за совершение коррупционных правонарушений, выступить основанием для предоставления различных преференций при осуществлении государственной поддержки, а также при реализации организациями, например, закупочной деятельности.

\section{Заключение}

Результаты проведенного исследования позволяют сделать выводы и внести некоторые предложения:

1. Коррупция как социальное негативное явление представляет угрозу национальной безопасности. Она проникла практически во все сферы жизнедеятельности общества. Политическая жизнь также не стала исключением. Политическая коррупция многогранна. Одной из форм политической коррупции является незаконное финансирование избирательных кампаний со стороны коммерческих организаций. Уголовно-правовой запрет на совершение указанных деяний закреплен в ст. 141.1 УК РФ, которая, однако, распространяется только на физических лиц и недостаточно эффективна на практике по ряду причин. Учитывая, что коррупционная деятельность коммерческих организаций остается за рамками уголовно-правового воздействия, приобретает актуальность 
разработка иных мер предупредительного воздействия, направленных на защиту электоральных отношений от коррупционных посягательств. К одной из таких мер следует отнести установление в локальных нормативных актах коммерческих организаций запрета на незаконное финансирование политической деятельности (избирательных кампаний).

2. На сегодняшний день в коммерческих организациях отсутствует единый подход к закреплению в локальных нормативных актах такого антикоррупционного стандарта поведения, как запрет на незаконное финансирование политической деятельности (избирательных кампаний). Причины этого могут быть весьма разнообразны. К одной из них следует отнести дефицит стимулирующих мер, побуждающих компании к добропорядочному ведению бизнеса, со стороны не только государства, но и руководства коммерческой организации. В этой связи предлагается:
2.1. Закрепить в законодательстве требование о наличии в проекте учредительного документа обязанности единоличного исполнительного органа разработать и утвердить антикоррупционную комплаенс-программу соответствующей организации.

2.2. Разработать на федеральном уровне типовой перечень корпоративных стандартов поведения, обязательных для включения в антикоррупционную комплаенспрограмму организации, и предусмотреть в нем запрет на незаконное финансирование политической деятельности (избирательных кампаний).

2.3. Стимулировать соблюдение коммерческими организациями антикоррупционных комплаенс-программ, включая запрет на незаконное финансирование политической деятельности (избирательных кампаний), посредством предоставления различных видов государственной поддержки.

\section{Список литературы / References}

Akunchenko, E.A. (2020). Korruptsionnaia prestupnost'v izbiratel'nom protsesse Rossiiskoi Federatsii [Corruption Crime in the Electoral Process of the Russian Federation]. Moscow, $232 \mathrm{p}$.

Antonova, E.Iu. (2013). Ugolovnaia otvetstvennost' korporativnogo (kollektivnogo) sub"ekta za korruptsionnoe prestuplenie [Criminal Liability of a Corporate (Collective) Subject for a Corruption Crime]. In Iuridicheskie issledovaniia [Legal Research], 3, 192-220. DOI: 10.7256/2305-9699.2013.3.568.

Antonova, E.Iu. (2020). Stimulirovanie antikorruptsionnogo povedeniia: opyt zarubezhnykh stran [Stimulating Anti-Corruption Behavior: The Experience of Foreign Countries]. In Antikorruptsionnaia bezopasnost': vyiavlenie ugroz i strategiia obespecheniia [Anti-Corruption Security: Identifying Threats and Ensuring Strategy]. Krasnoyarsk, 24-29.

Astanin, V.V. (2016). Antikorruptsionnaia ekspertiza v voprosakh doktriny i praktiki [Anti-Corruption Expertise in Issues of Doctrine and Practice]. In Rossiiskaia iustitsiia [Russian Justice], 8, 5-9.

Astanin, V.V. (2017). Korporativnyi antikorruptsionnyi komplaens: problemy i resursy prakticheskogo obespecheniia [Corporate Anti-Corruption Compliance: Problems and Resources of Practical Support]. In Rossiiskaia iustitsiia [Russian Justice], 10, 5-8.

Astanin, V.V. (2017). O realiiakh i zadachakh korporativnogo antikorruptsionnogo komplaens [On the Realities and Tasks of Corporate Anti-Corruption Compliance]. In Monitoring pravoprimeneniia [Monitoring of Law Enforcement], 3, 4-9.

Avak'ian, S.A. et al. (2016). Protivodeistvie korruptsii: konstitutsionno-pravovye podkhody [Anti-Corruption: Constitutional and Legal Approaches]. Moscow, 512 p.

Bobrova, N.A. (2013). O sovershenstvovanii zakonodatel'stva i praktiki privlecheniia k ugolovnoi otvetstvennosti za narusheniia poriadka finansirovaniia izbiratel'noi kampanii [On Improving the Legislation and Practice of Bringing to Criminal Responsibility for Violations of the Procedure for Financing the Election Campaign]. In Vestnik samarskogo gosudarstvennogo universiteta [Bulletin of the Samara State University], 8-1, 5-14. 
CPI, 2021 - Rossiia v Indekse vospriiatiia korruptsii-2020: 30 ballov i 129 mesto [Russia in the Corruption Perception Index-2020: 30 points and 129th place]. Available at: https://transparency.org.ru/research/ indeks-vospriyatiya-korruptsii (accessed February 12, 2021).

Damm, I.A. (2003). Poniatie, priznaki i vidy korruptsii [The Concept, Signs and Types of Corruption]. In Preduprezhdenie korruptsii v sisteme ugolovnoi iustitsii [Prevention of Corruption in the Criminal Justice System]. Krasnoyarsk, 117-127.

Damm, I.A. (2006). Korruptsiia v rossiiskom izbiratel'nom protsesse: poniatie i protivodeistvie [Corruption in the Russian Electoral Process: Concept and Counteraction], PhD diss., Krasnoyarsk State University.

Damm, I.A. (2018). Korruptsiia v izbiratel'nom protsesse kak ob"ekt kriminologicheskogo poznaniia [Corruption in the Electoral Process as an Object of Criminological Knowledge]. In Antikorruptsionnaia bezopasnost': vyiavlenie ugroz i strategiia obespecheniia [Anti-Corruption Security: Identifying Threats and Ensuring Strategy]. Krasnoyarsk, 13-26.

Devitskii, E.I. (2014). O problemnykh voprosakh finansirovaniia izbiratel'nykh kampanii kandidatov, izbiratel'nykh ob"edinenii [On Problematic Issues of Financing Election Campaigns of Candidates and Electoral Associations]. In Izbiratel'noe parvo [Electoral Law], 2, 32-42.

Eliseeva, T.N. (2004). Ugolovno-pravovaia okhrana izbiratel'nykh prav grazhdan Rossiiskoi Federatsii [Criminal Legal Protection of Electoral Rights of Citizens of the Russian Federation], Abstract of PhD diss., Moscow Institute of the Ministry of Internal Affairs of the Russian Federation.

Fedorov, A.V. (2015). Ugolovnaia otvetstvennost' iuridicheskikh lits za korruptsionnye prestupleniia [Criminal Liability of Legal Entities for Corruption Crimes]. In Zhurnal rossiiskogo prava [Journal of Russian Law], 1, 55-63. DOI: 10.12737/7249.

Feshchenko, P.N. (2015). Kriminologicheskii vzgliad na mesto korruptsii i sotsial'noi napriazhennosti v sisteme prichin "tsvetnykh revoliutsii" [Criminological View on the Place of Corruption and Social Tension in the System of Causes of "Color Revolutions"]. In Korruptsiia: sostoianie protivodeistviia $i$ napravleniia optimizatsii bor'by [Corruption: The State of Counteraction and Directions for Optimizing the Fight]. Moscow, 78-85.

Forbes, 2020 - 200 krupneishikh kompanii Rossii [200 largest companies in Russia]. Available at: https://www.forbes.ru/rating/409143-200-krupneyshih-chastnyh-kompaniy-rossii-2020-reyting-forbes (accessed February 12, 2021).

Golovin, A.G. (2016). Izbiratel'noe pravo i izbiratel'nyi protsess v Rossiiskoi Federatsii [Electoral Law and the Electoral Process in the Russian Federation]. Moscow, $256 \mathrm{p}$.

Gorshenkov, G.N. (2016). Effektivnost' antikorruptsionnoi politiki [Effectiveness of Anti-Corruption Policy]. In Aktual'nye problemy ekonomiki i prava [Relevant Problems of Economics and Law], 1, 5-16.

Grashchenkov, I.A., Meier, M.M. (2016). Faktor vliianiia finansovo-promyshlennykh grupp na regional'nuiu politiku [Influence Factor of Financial and Industrial Groups on Regional Policy], In Vlast' [Power], 7, 85-89.

Kabanov, P.A. (2003). Nekotorye naibolee opasnye negativnye sotsial'nye posledstviia politicheskoi korruptsii dlia sovremennogo rossiiskogo obshchestva [Some of the Most Dangerous Negative Social Consequences of Political Corruption for Modern Russian Society]. In Sotsiologiia korruptsii [Sociology of Corruption]. Moscow, 188-195.

Kabanov, P.A. (2004). Politicheskaia korruptsiia v Rossii: poniatie, sushchnost', prichiny, preduprezhdenie [Political Corruption in Russia: Concept, Essence, Causes, Prevention]. Nizhnekamsk, 174 p. DOI: 10.13140/RG.2.1.2095.0164.

Kabanov, P.A. (2018). Antikorruptsionnoe protsessual'noe zakonodatel'stvo sub"ektov rossiiskoi federatsii: formirovanie i soderzhanie [Anti-Corruption Procedural Legislation of the Subjects of the Russian Federation: Formation and Content]. In Aktual'nye problemy ekonomiki i prava [Relevant Problems of Economics and Law], 2, 300-333. DOI: 10.21202/1993-047X.12.2018.2.300-333.

Kakitelashvili, M.M. (2017). Praimeriz kak instrument nezakonnoi finansovoi podderzhki na vyborakh [Primaries as an Instrument of Illegal Financial Support in Elections]. In Zakony Rossii: opyt, analiz, praktika [Laws of Russia: Experience, Analysis, Practice], 2, 65-70. 
Kardopolov, Iu.F. (2005). Metody kriminologicheskikh issledovanii [Methods of Criminological Research]. Krasnoyarsk, 202 p.

Kashepov, V.P. (2015). Ugolovnaia otvetstvennost' iuridicheskikh lits za korruptsionnye prestupleniia [Criminal Liability of Legal Entities for Corruption Crimes]. In Zhurnal rossiiskogo prava [Journal of Russian Law], 3, 90-101. DOI: 10.12737/7880.

Kleimenov, M.P. (2018). Kriminologicheskoe zakonodatel'stvo i kriminologicheskoe pravo v Rossii [Criminological legislation and criminological law in Russia], In Lex russica, 2, 148-159. DOI: 10.17803/1729-5920.2018.135.2.148-159.

Kleimenov, M.P. (2020). Kriminologicheskie aspekty konspirologii [Criminological Aspects of Conspirology]. In Vserossiiskii kriminologicheskii zhurnal [Russian Journal of Criminology], 14 (4), 531-540. DOI: 10.17150/2500-4255.2020.14(4).531-540.

Kozlov, T.L. (2020). Perspektivy razvitiia rossiiskogo zakonodatel'stva o protivodeistvii korruptsii [Prospects for the Development of Russian Legislation on Combating Corruption]. In Zhurnal rossiiskogo prava [Journal of Russian Law], 5, 158-166. DOI: 10.12737/jrl.2020.063.

Liu, G., Liu, S. (2017). Corruption crime and punishment: Evidence from China's state corruption audits. In Journal of Financial Crime, 24 (4), 601-619. DOI: 10.1108/JFC-06-2016-0044.

Lopashenko, N.A. (2009). Ugolovnaia politika [Criminal Policy]. Moscow, 579 p.

Matskevich, I.M., Aminov I.I. (2017). Normativno-pravovye mekhanizmy protivodeistviia korruptsionnym riskam za rubezhom [Normative-Legal Mechanisms of Countering Corruption Risks Abroad]. In Gosudarstvennaia sluzhba $i$ kadry [Public service and personnel], 4, 116-120.

Methodological recommendations, 2014 - Metodicheskie rekomendatsii po razrabotke i priniatiiu organizatsiiami mer po preduprezhdeniiu i protivodeistviiu korruptsii [Methodological Recommendations for the Development and Adoption by Organizations of Measures to Prevent and Combat Corruption]. Available at: https://mintrud.gov.ru/ministry/programms/anticorruption/015/0 (accessed February 12, 2021).

News, 2011 - Eks-deputat Novovoronezhskoi gordumy eshche raz predstanet pered sudom [Ex-Deputy of the Novovoronezh City Duma Will Once Again Appear Before the Court]. Available at: https://www. kommersant.ru/doc/1808471 (accessed February 12, 2021).

Nisnevich, Iu.A. (2012). Politicheskaia korruptsiia: opredelenie, formy proiavleniia, mekhanizm i resursy [Political Corruption: Definition, Forms of Manifestation, Mechanism and Resources]. In Tekhnologizatsiia politicheskikh protsessov v usloviiakh globalizatsii: teoriia, opyt, perspektivy [Technologization of Political Processes in the Context of Globalization: Theory, Experience, Prospects]. Moscow, 193-201.

Nisnevich, Iu.A. (2015). Korruptsiia $\mathrm{v}$ istoricheskoi retrospektive s utochneniiami i dopolneniiami [Corruption in Historical Retrospect with Clarifications and Additions]. In Obshchestvennye nauki i sovremennost' [Social Sciences and Modernity], 3, 90-100.

Nomokonov, V.A. (2013). Korruptsiia v Rossii: sotsial'nye posledstviia i osobennosti prichin [Corruption in Russia: Social Consequences and Features of Causes]. In Aktual'nye problemy ekonomiki i prava [Relevant Problems of Economics and Law], 4, 61-67.

Nomokonov, V.A. (2014). Bor'ba s korruptsiei v Rossii: pervye itogi [Fight Against Corruption in Russia: First Results]. In Tamozhennaia politika Rossii na Dal'nem Vostoke [Customs Policy of Russia in the Far East], 2, 88-100.

Rogachevskii, L.A. (2015). Ambitus: elektoral'naia korruptsiia v Rimskoi Respublike i rannei Rimskoi Imperii (praktika vyborov i zakonodatel'stvo) [Ambitus: Electoral Corruption in the Roman Republic and the early Roman Empire (Practice of Elections and Legislation)]. In Izvestiia vysshikh uchebnykh zavedenii. Pravovedenie [The News of Higher Educational Institutions. Jurisprudence], 1, 162-196.

Rose-Ackerman, S. (2003). Korruptsiia i gosudarstvo. Prichiny, sledstviia, reformy [Corruption and the State. Causes, Consequences, Reforms]. Moscow, 343 p.

Shchedrin, N.V. (2018). Problemy i perspektivy kriminalizatsii nezakonnogo obogashcheniia publichnykh dolzhnostnykh lits [Problems and Prospects of Criminalization of Illegal Enrichment of Public Officials]. In Imushchestvennye otnosheniia v Rossiiskoi Federatsii [Property Relations in the Russian Federation], 12, 62-75. DOI: 10.24411/2072-4098-2018-10127. 
Shevchenko, G.N. (2006). Ugolovno-pravovaia okhrana izbiratel'nykh prav grazhdan [Criminal Legal Protection of Citizens' Electoral Rights], PhD diss., Rostov Law Institute of the Ministry of Internal Affairs of the Russian Federation.

Sheverdiaev, S.N. (2020). Konstitutsionnoe zakonodatel'stvo o protivodeistvii politicheskoi korruptsii: sistema i perspektivy [Constitutional Legislation on Countering Political Corruption: System and Prospects]. In Gosudarstvennaia vlast' i mestnoe samoupravlenie [State Power and Local Self-Government], 1, 45-52. DOI: 10.18572/1813-1247-2020-1-45-52.

Statistic Data, 2020 - Sostoianie prestupnosti v Rossii za ianvar' - dekabr' 2020 goda [The state of crime in Russia for January-December 2020]. Available at: http://crimestat.ru/analytics (accessed February 12, 2021).

Statistic Data, 2021 - Dannye sudebnoi statistiki [Data of judicial statistics]. Available at: http://www. cdep.ru/index.php?id=79 (accessed February 12, 2021).

Tolstikova, I.N. (2005). Ugolovnaia otvetstvennost' za narusheniia zakonodatel'stva o vyborakh [Criminal Liability for Violations of the Legislation on Elections], Abstract of PhD diss., Krasnoyarsk State University.

Tsirin, A.M. (2016). Preduprezhdenie korruptsii: problemy i perspektivy [Prevention of Corruption: Problems and Prospects]. In Zhurnal rossiiskogo prava [Journal of Russian Law], 12, 106-115. DOI: $10.12737 / 22727$.

Turishcheva, N.Iu. (2010). Prestupleniia protiv izbiratel'nykh prav i prava na uchastie v referendum [Crimes Against Electoral Rights and the Right to Participate in the Referendum]. Saint-Petersburg, $337 \mathrm{p}$.

Zhubrin, R.V., Ilii S.K. (2017). Problemy vozmeshcheniia ushcherba ot korruptsionnykh prestuplenii i pravonarushenii [Problems of Compensation of Damage from Corruption Crimes and Offenses]. In Vestnik Akademii General'noi prokuratury Rossiiskoi Federatsii [Bulletin of the General Prosecutor's Office Academy of the Russian Federation], 3, 70-77.

Zyrianova, I.A. (2013). Izbiratel'nyi shtab kandidata - sub"ekt korruptsii v izbiratel'nom protsesse? [Candidate's Election Headquarters - Is a Subject of Corruption in the Electoral Process?]. In Aktual'nye problemy ekonomiki i prava [Relevant Problems of Economics and Law], 4, 32-37. 